\title{
BEACH TOURISM PLANNING BASED ON GOOD GOVERNANCE PERSPECTIVE
}

\author{
Fahmi Ahmad*, Zauhar Soesilo, Noor Irwan \\ Master's Program in Public Administration, Faculty of Administrative Science, \\ University of Brawijaya, Indonesia \\ *E-mail: fahmitadung@gmail.com
}

\begin{abstract}
Tourism development is one of the priority programs of the regional development. The reason is that the effect of tourism development can improve the regional economy. However, in order to improve the regional economy, tourism development should be managed based on the good governance. This research aims to identify the development planning of the Ujung Pandaran. This tourist attraction is one of the leading tourisms in Kotawaringin Timur Regency, Central Kalimantan Province, Indonesia. This research uses qualitative research type with analysis method proposed by Miles, Hubberman, and Saldana. The research results show that the tourism development planning of Ujung Pandaran beach has some limitations. The example of the limitation of the planning is the absence of feasibility analysis process and evaluation stage for the planning that has been determined. The failure of this process has impacted the implementation stage. The cooperation planning with the private sector that has been determined cannot be realized properly. Meanwhile, the existence of private sector participation in the tourism development is one of the criteria of tourism development planning based on the good governance perspective.
\end{abstract}

\section{KEY WORDS}

Planning, tourism, good governance, policy, development.

Tourism has been established as one of the leading sectors in Indonesia. It can be seen through the National Medium Term Development Plan of Indonesia in 2015 which establish tourism development as one of the priority programs of development. The reason is that Indonesia has the potential of abundant tourism resources, be it nature, culture or artificial travel. Based on the performance report of the Ministry of Tourism (2016), the tourism sector has accounted for the National Gross Domestic Product by $10 \%$ which is the highest in ASEAN and has the Tourism GDP growth above the industry average. Then, tourism is ranked fourth nationally accounted for foreign exchange in the amount of $9.3 \%$. As well as contributing 9.8 million jobs, equivalent to $8.4 \%$ and grew by $30 \%$ within 5 years.

Kotawaringin Timur Regency is a regency in Central Kalimantan province were classified as rich in natural resources and is as an economic gateway in Central Kalimantan province with the progress upstream and downstream industries as well as the cities of goods and services. One sector that is expected to contribute significantly to the development of the future for the District Kotawaringin Timur is the tourism sector. According to Pendit (2006: 217), the tourism sector is one of the alternatives that could be developed to foster development in an area.

One of the potentials of natural resources contained in the District Kotawaringin Timur is Ujung Pandaran beach tourism. The beach with its unique natural beauty characteristic white sand and a wealth of marine life as well as wooded stretches as far as tens of kilometers from the district to the border with the District Kotawaringin Timur Seruyan. So this Ujung Pandaran beach serves as the dominant sector of the district.

The role of tourism is very important, especially the nature of the tourism multiplier effect is certainly very potential to be developed. If the tourism sector can be managed with both the revenue received in the form of revenue (PAD) can be used in financing the needs of the local government is autonomous and independent. Even Pendit (1994: 239) disclose the results of Conference on International Travel and Tourism stated that basically, tourism was not as a source of income alone, but more than that tourism has the ability as a 
determining factor for the success of the local industry and the development of the areas that the poor will be the source natural.

In the development of tourism must be through good planning-oriented governance. Fundamentally, good governance is a responsible and consistent management of efficient democratic and market principles, avoiding misallocation of investment funds and preventing corruption both politically and administratively (LAN, 20006). Therefore, the existence of good governance is believed to have an impact on the success of tourism development plans.

Tjokroamidjojo (2006) argued that an understanding of the conception of good governance can be explained by principles such as accountability, transparency, openness, under the law, and guarantee fair treatment. Implementation of Good Governance in the development of the tourism sector includes three (3) main elements, namely the government, the private sector which represents the employers in tourism and the community that supports tourism. By involving all elements of good governance are expected to be able to overcome the problems of the tourism sector. Good Governance in the field of tourism development planning is a necessity, otherwise, if the development planning of tourism without being based on the Good Governance causing partial plan is not integral.

As regulated in Act no. 10 of 2009 which states that tourism is an integral part of the national development that is done systematically, integrated, and sustainable. In addition, the ongoing tourism activities are required to be able to synergize the interests of inter-sector, regional, center with areas that have close ties and synergize the integration among stakeholders in it as a systemic unit within the framework of Regional Autonomy and synergize the integration between the existing stakeholders inside it.

Therefore, this paper intends to analyze and to know whether in the planning of coastal tourism development Ujung Pandaran have based on a perspective of good governance. So the expectations, this paper will be useful as a study, especially for local governments in development planning Sampit Regency leading tourist attraction of the area.

\section{METHODS OF RESEARCH}

This research has been conducted for 4 months from December 2017 until March 2018. This research uses descriptive qualitative research type. Through direct observation and interviews to stakeholders, and with additional secondary data such as a strategic document, some pictures and so on aims to describe the planning of tourism development on the coast of UjungPandaran Kotawaringin Timur, Central Kalimantan Province.

The analysis technique used in this research is using mode released by Miles and Hubberman (2014) with the steps that must be done is:

1. Data condensation refers to the process of selecting, simplifying, focusing, abstracting and altering data that has been collected in field notes, transcript interviews, documents and other empirical materials. Condensation can make data stronger and occur continuously during qualitative research. Things done on the condensation data are writing summaries, coding, developing themes, generating categories and writing analytic memos.

2. Display data is a short parse such as a chart, the relationship between categories and types. At this step, the processed data is then further analyzed in depth and thorough to facilitate the understanding of the narrative text. Then the analysis is entered into groups according to their respective themes then described and then analyzed again thoroughly.

3. Conclusion Drawing or verification is an activity to test the truth of every meaning that emerges as well as the classification of data that has been made through the chart. The preliminary conclusions raised are temporary and will change if there is no strong evidence to support the next stage of data collection. The data presented are tested truthfully by analyzing and clarifying them again. 


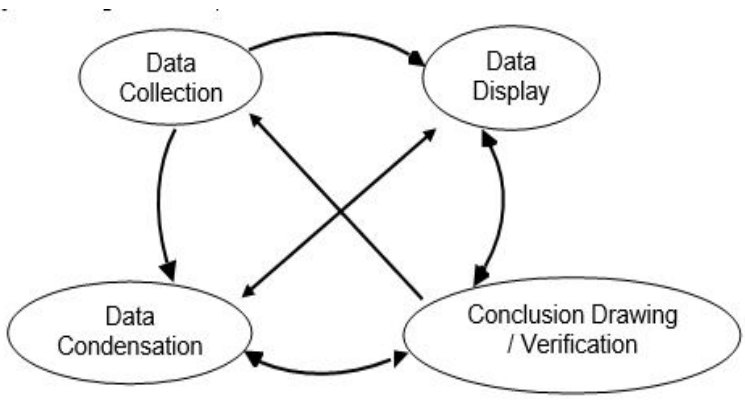

Figure 1 - Interactive Analysis Model by Miles and Hubberman (2014)

\section{RESULTS OF STUDY}

Tourism Potential of Kotawaringin Timur Regency. Kotawaringin Timur Regency has attractive natural resources, especially for tourism. With natural resources owned, making this district into a tourist attraction leading tourist sector. Potential tourism owned this district is as follows:

Table 1 - Tourism Potential of Kotawaringin Timur Regency

\begin{tabular}{cll}
\hline No. & Type & \multicolumn{1}{c}{ Name } \\
\hline 1 & Nature & Ujung Pandaran Beach and Mangrove Forest \\
2 & Cultural & Simah Laut and funeral \\
3 & Artificial & FishPond \\
\hline
\end{tabular}

Source: Processed Data.

The natural wealth owned by East Kotawaringin Regency is a beach called Ujung Pandaran beach. The location of this beach is located in District Sampit. Ujung Pandaran Beach has become a leading tourist attraction because it also has a mangrove forest that can be used as a tourist attraction. In addition, there is also the potential that comes from local cultures such as Simah Laut and funeral. And then, has the potential of artificial tourism is the existence of fish ponds.

It can be seen from Fig. A1 that the location of Ujung Pandaran beach is very strategic. Adjacent to the burial place of one scholar called Al-Alimulallaamah $\mathrm{H}$. Sheikh Hamid Bin Abu Al-Alimulallaamah $\mathrm{H}$. Mufti Sheikh Muhammad As'ad. He was the great-grandfather of one of the well-known scholars in the island of Borneo and is highly respected by the people, namely Datuk Kalampayan Sheikh Arsyad Muhammad Al-Banjari. He was an author of science books of fiqh Sabillal Muhtaddin. Many people visit for the purpose of pilgrimage. Because he was someone who has an important role in the spread of Islam.

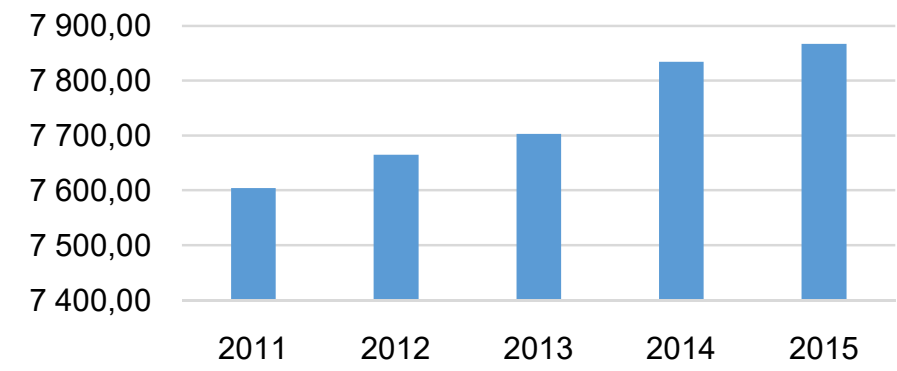

Figure 2 - Fishery Production in Ujung Pandaran Beach, Ton (Source: BPS Kotim Regency)

Another artificial potential that culinary tourism. With the strategic location of the beach with sea looks beautiful, it also has the potential of marine fish. So many people visit as well as to purchase various types of fresh fish caught by the fishermen. Fishing activities that 
were fishing with a boat and came up with catches from the sea can be seen directly. Visitors who come can also rent boats owned by fishermen to tour the region along the coast as a means of transportation to get to the station sacred religious tourism or fishing in the sea.

Addition based on a strategic coastal location, coastal tourism Ujung Pandaran also has the potential of culture-based. Local communities have a culture called the "Simah Laut", which is a cultural ritual to take away from unfortunate carried out by the local village of fishing communities in the implementation of area locations Ujung Pandaran beach tourism. Simah Laut in the form of a special ritual ceremony by using different terms in the form of a special dish into the sea with mythical.

Development Planning Tourism of Ujung Pandaran Beach. This study is based on a planning model that had been developed by the Department of Culture and Tourism related Kotawaringin Timur district development planning Ujung Pandaran leading tourist beach. The planning process is set out in the Strategic Plan of the Department of Culture and Tourism. However, the planning process is the reference Kotawaringin Timur District tourism development is tourism development plan of the Ministry of Tourism. The process is shown in Figure 3 below:

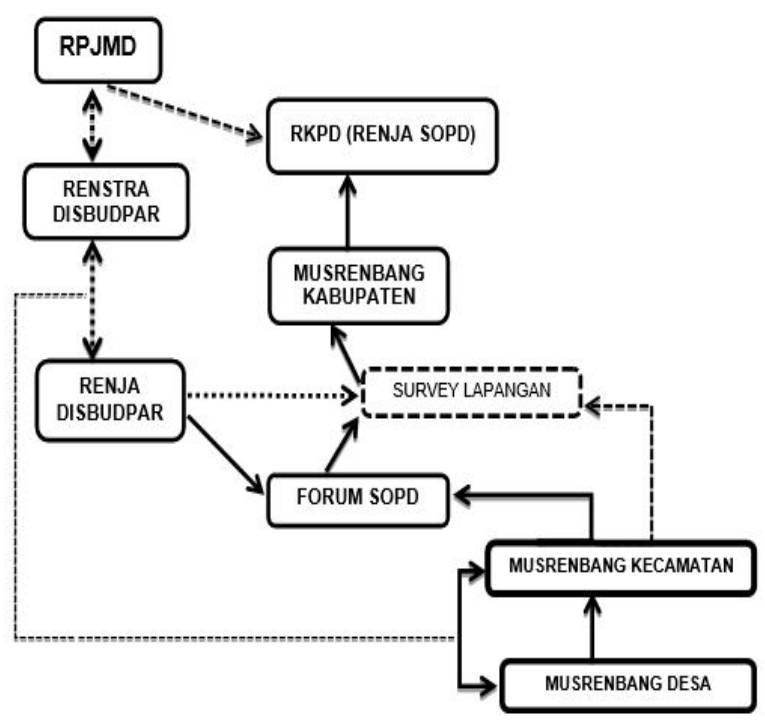

Figure 3 - Model of Tourism Development Planning Process (Source: Disbudpar Kotim, 2018, Processed)

\section{DISCUSSION OF RESULTS}

As shown in figure $\mathrm{A} 1$, Ujung Pandaran a leading tourist sector because it has a strong potential. The potential of not only potential source of natural resources but also originating from the culture and history of the local environment such as "Simah Laut" and the funeral of a famous person who is one of the propagators of the Muslim religion.

The first potential is called "Simah Laut". Simah Laut is a culture of ritual ceremony that aims to keep away from all the misfortune committed by local fishing communities. The implementation of this ceremony conducted at the location of coastal tourism area Ujung Pandaran. "Simah Laut" is a ritual ceremony by providing various things as a special form of offering to the sea of mystical nuance. By the local community, this cultural ritual is believed to bring safety and provide an abundance of fortune during head seaward.

The second potential is religious tourism called "cemetery". There is a funeral one of the scholars in the area of coastal tourism Ujung Pandaran, namely Al-alimulallaamah $\mathrm{H}$. Sheikh Hamid Bin Abu Al-Alimulallaamah H. Mufti Sheikh Muhammad As'ad which is a greatgrandfather of one of the well-known scholars in the island of Borneo (Datuk Kalampayan sheikh Muhammad Al-Banjari Arsyad an author of science books of figh Sabillal Muhtaddin). 
The tomb is visited by people with the intention to make pilgrimage because it is the tomb of one of the scholars who also have an important role in the spread of Islam.

Third potential is culinary tour. At the time while entering the coastal tourism area Ujung Pandaran, visitors will find a variety of fresh fish that catch from the sea. The price offered will be cheaper and have a big difference in the market price. In fact, fish that have been purchased and selected by the visitors can be requested to be cooked by the sellers/owners of food stalls located in the area.

In addition to the appeal of such attractions as stated above, other attractions are found in the coastal areas of Ujung Pandaran namely fishing community activities were fishing with a boat and came up with catches from the sea can be seen directly. Visitors who come can also rent a boat belonging to the fishing community to tour the region along the coast as a means of transportation to get to the station sacred religious tourism or fishing in the sea.

The diversity of the appeal (points) travel and public life behavior village of Ujung Pandaran contained in the sights or the environment around it is a resource that can be used for a variety of tourism activities, one of the characteristics of tourism resources is to be vandalized and destroyed by the use of the uncontrolled and errors in its use.

The potential of this kind needs to be developed to be able to boost the regional economy. In developing the potential of this kind need a better plan and based on good governance.

The conception of good governance proposed Tjokroamidjojo (2006) is that it should have the principles of accountability, transparency, openness, under the law and guarantee fair treatment. That is, in the planning of tourism development of Ujung Pandaran beach must refer to the principle.

The results showed that the process of development planning of Ujung Pandaran beach already has the principles of accountability, transparency, fair treatment under the law draft. In making the plan, the Department of Culture and Tourism has been referred to several laws such as Act No. 25 of 2004 on National Development Planning System in which states that in the development planning process must go through the forum Musrenbang from the village level, and the District. The musrenbang forum serves as a forum or community facility to freely provide advice or feedback on the program to be designated as a development plan. Thus, through this activity has accommodated the principles of good governance, such as participation, transparency, accountability and fair treatment for all stakeholders to provide input.

Linking tourism development planning of Ujung Pandaran Beach based on a theory proposed by Mahi and Trigunarso (2017), that in a development plan has several components that must be passed. 1) That the Department of Culture and Tourism should have diagnosed the problem. This means, that in preparing a plan seen through strategic issues that have. The issues set out in the presence of the tourism potential but not optimal in its management; low quality and quantity of supporting infrastructure; not optimal promotion; lack of community tourism awareness; and yet the development of the creative economy based on tourism. 2) Formulation of objectives. Based on these issues, the government set the goal of synchronization results on the vision and mission of the Regional Medium Term Development Plan. That is increasing the quantity and quality of tourism products and tourism resources. 3) Projection. In this case, the government has estimated the programs that support the creation of the necessary budget and their objectives. 4) Feasibility analysis, 5) evaluation. Components of feasibility and evaluation analysis have not been seen in the planning process of Ujung Pandaran Beach tourism development. 6) Implementation, through the implementation will be known if the process of tourism development planning has been based on good governance.

Implementation of Good Governance in the development of the tourism sector includes three (3) main elements, namely the government, the private sector which represents the employers in tourism and the community that supports the tourism sector (Sedamayanti, 2013; Ganie, 2000). In the process of development planning of Ujung Pandaran beach, the government has involved the community in determining development programs. 
The program plan specified in Ujung Pandaran beach tourism development has been referring to the 3 pillars of good governance. The role of government in involving the public and private sector in tourism development. However, in the Implementation within 2 years, the government only implements the involvement of the community in awareness of tourism such as giving counseling and empowerment to the community. While the private sector has not been involved in the development of Ujung Pandaran beach tourism. It can be seen through the table A1 related tourist facilities were inadequate, and the lack of adequate market system interactions in tourist areas.

The lack of private sector involvement in the development planning of Ujung Pandaran beach tourism is due to the limited competence of the local government. It can be seen through the specified programs. The program planning is done in order to develop a leading tourist attraction East Kotawaringin not optimal. Due to the planned investment cooperation program lacks clarity related to the desired form of investment.

Until now, the state of the existing facilities at the attraction is still inadequate. The results showed that the reasons for lack of development and construction of tourist infrastructure are due to lack of funds owned by the government. This indicates that local governments do not accommodate what private sector roles have been planned for investment cooperation programs. This also indicates that the competence of personnel resources and still not up in the planning of tourism development. In fact, if the cooperation programs and activities defined investment can be optimized, then the issue of public service provision in the tourist area can be resolved. As Partnership (2003) stated that with the participation of the private sector in tourism development planning will lead to many benefits such as the availability of alternative sources of financing; faster implementation of infrastructure provision; Budgets and risk reduction in the burden of government; The infrastructure can be provided more and more; the better performance of public services; accountability can be improved; and the private sector could contribute capital, technology, and managerial skills.

\section{CONCLUSION}

In this research has indicated that the development planning process of Ujung Pandaran Beach tourist object does not pass the feasibility analysis stage and evaluation stage before the implementation stage. So that programs that have been set cannot be implemented properly as well as cooperation with the private sector. It can be seen through the availability of existing infrastructure in Ujung Pandaran Beaches inadequate. Though this infrastructure is one of the charms that elevate visitors. Cooperation with the private sector that is not implemented in the construction of coastal tourism object Ujung Pandaran due to lack of clarity of planning activities that have been determined. This happens because of lack of competence possessed apparatus. So it is necessary to empower the apparatus of the development planning process through assistance by a team of planning experts.

\section{RECOMMENDATIONS}

Based on the results of research, can be known weaknesses that occur in the planning of the development of superior tourist attraction of Ujung Pandaran beach. The weakness is the lack of knowledge and skills of apparatus resources in planning the development of tourism object. The reason is that of the absence of feasibility analysis and evaluation process, the absence of excellent programs that become the main priority in tourism development and the lack of clear partnership program planned so that at the implementation stage there is still no cooperation with the private sector. Therefore, we give recommendation suggestion that in order to improve the quality of planning, it is the necessary empowerment of apparatus accompanied by the team of planning expert by cooperating with the academic sector as an expert team. The empowerment of such apparatus will broaden the apparatus's knowledge of tourism development planning so that the resulting planning can be qualified. With the increased insight also may increase the apparatus in carrying out cooperation with private sector investment, especially in infrastructure. 


\section{APPENDIX}

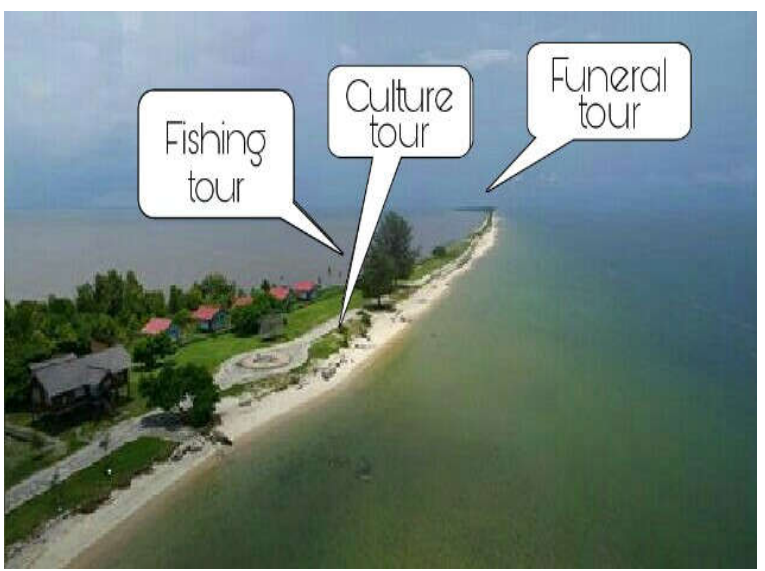

Figure A1 - Picture of Ujung Pandaran Beach

Table A1 - Ujung Pandaran Beach Tourism Facilities

\begin{tabular}{|l|l|l|}
\hline \multicolumn{1}{|c|}{ Name } & Amount & \\
\hline Big House & 1 & - \\
\hline Home Stay & 10 & - \\
\hline Public bathroom & 5 & - \\
\hline Public toilet & 5 & - \\
\hline Cottage & 5 & 3 broken \\
\hline Gazebo & 5 & 2 broken \\
\hline Stage show & 1 & - \\
\hline Mushola & 1 & - \\
\hline Electricity & - & - \\
\hline Road access & - & - \\
\hline Trash can & 4 & - \\
\hline Clean water access & 1 & 2 water pump machine and 2 water container (20.000 liter) \\
\hline
\end{tabular}

\section{REFERENCES}

1. Ganie, R.M. 2000. Good Governance: Prinsip, Komponen dan Penerapannya dalam HAM. Jakarta: Bappenas

2. Lembaga Administrasi Negara (LAN) RI. 2000. Akuntabilitas dan Good Governance, Modul Sosialisasi Sistem Akuntabilitas Kinerja Instansi Pemerintah. (AKIP). Jakarta.

3. Mahi, A.K and Trigunarso, S.I. 2017. Perencanaan Pembangunan Daerah (Teori dan Aplikasi). Jakarta: Prenadamedia Group

4. Miles, Matthew B, A. Michael Huberman and Johnny Saldana, 2014, Qualitative Data Analysis, A Methods Sourcebook, Edition 3, Los Angeles: Sage Publication: Inc.

5. Pendit, Nyoman S. 2006. Ilmu Pariwisata (Sebuah Pengantar Perdana). Jakarta: PT. Pradnya Paramita.

6. Undang-undang Nomor 25 Tahun 2004 Tentang Sistem Perencanaan Pembangunan Nasional (Lembaran Negara Republik Indonesia Tahun 2004 Nomor 104, Tambahan Lembaran Negara Republik Indonesia Nomor 4421).

7. Undang-Undang Nomor 10 Tahun 2009 Tentang Kepariwisataan.

8. Sedarmayanti. 2013. Good Governance (Kepemerintahan Yang Baik) Dalam Rangka Otonomi Daerah.Bandung: Mandar Maju.

9. Tjokroamidjojo, B. 2006. Good Governance. Jakarta: UI-Press. 